\title{
Reinvestigating the Reciprocal Relationship between Democracy and Income Inequality
}

\author{
Carl Henrik Knutsen ${ }^{\bowtie}$ \\ University of Oslo
}

\begin{abstract}
Few social science relationships have spawned as much interest - or as many elaborate theoretical models and arguments - as that between democracy and income inequality. However, the empirical literature has generally employed statistical models based on problematic assumptions, and has produced quite mixed results. Hence, this paper makes an important empirical contribution by applying models that, for instance, account for endogeneity biases and control for country-specific effects. Despite being correlated, there is very little evidence of any effect of income inequality on level of democracy once employing appropriate model specifications. Furthermore, there is no robust evidence that inequality systematically affects either democratization prospects or democratic stability. In contrast, there is evidence that democracy reduces income inequality when inequality is proxied by share of income going to wages. However, also this effect is sensitive to the choice of inequality measure. Democracy does, for instance, not reduce inequalities in disposable household incomes.
\end{abstract}

JEL classification: D02; D63; 010; P00

Keywords: Democracy; Income Inequality; Democratization; Democratic stability; Wage income; Redistribution

The author would like to thank Sirianne Dahlum, Abel Escriba Folch, Christian Houle, Kalle Moene, Gerardo Munck, Andrea Presbitero, Asmund Rygh, Svend-Erik Skaaning, Tore Wig, Simone Wegmann and anonymous reviewers, as well as participants at the "Democracy and Democratization in Comparative Perspective Workshop" at Aarhus University, the "Constitutions, Cultures, Practices Workshop" at the University of Oslo, and the 2nd Annual EPSA Conference in Berlin, for very helpful comments and suggestions. A special thanks to Lars Petter Berg and Selemon Negash for excellent research assistance.

${ }^{凶}$ Address: Department of Political Science, University of Oslo, Eilert Sundts hus, Moltke Moes vei 31, 0851 Oslo, Norway. (Phone: +47 228 54244. Email: c.h.knutsen@stv.uio.no).

\section{Recommended Citation}

Knutsen, C. H. (2015). Reinvestigating the Reciprocal Relationship between Democracy and Income Inequality. Review of Economics and Institutions, 6(2), Article 1. doi: 10.5202/rei.v6i2.173.

Retrieved from http://www.rei.unipg.it/rei/article/view/173 


\section{Introduction}

Does democracy reduce income inequality? Or, does income inequality affect the prospects for democratization or democratic survival? The empirical analysis in this paper revisits these important questions. It contributes to the literature by accounting for the possible two-way causal relationship between regime type and income inequality, but also by acknowledging that country- and time-specific factors, sample selection biases, and choice of regime and inequality measures may influence results.

Few social science relationships have generated as much interest as that between democracy and income inequality, resulting in numerous theoretical accounts. Several scholars have, quite convincingly, argued that democracy thrives in more egalitarian contexts. However, influential contributions have also highlighted mechanisms through which high income inequality could spur democratization (e.g., Acemoglu and Robinson 2006). Similarly, an extensive literature explains how democracy may reduce income inequality. But, models producing this implication may rely on too simplistic assumptions regarding political processes in democracies (e.g., Ansell and Samuels 2010), and technological and other structural factors could matter far more for inequality than political factors (Mulligan et al. 2004). These ambiguities are reflected in the empirical literature, where different contributions find diverging results both for the effect of income inequality on democracy and of democracy on inequality.

The lack of any robust aggregate relationship between inequality and democracy might stem from the relationship being highly contingent on other factors, such as opposition groups' capabilities in overcoming collective action problems or economic openness (see, e.g., Haggard and Kaufman 2012; Freeman and Quinn 2012). Nevertheless, previous studies - often relying on small samples or improperly specified models - may simply have arrived at the wrong conclusions on whether income inequality has any net effect on level of democracy (or vice versa). Few empirical studies have systematically taken endogeneity into account (but, see Rubinson and Quinlan 1977; Bollen and Jackman 1985; Burkhart 1997, 2007), despite plausible theoretical arguments for a two-way causal relationship. Furthermore, most studies have included only small subsets of the world's countries and used cross-sectional data or time series for a handful years (but, see Houle 2009; Teorell 2010; Timmons 2010; Acemoglu et al. 2013). This could lead to estimates with low reliability and to sample-selection biases affecting results.

This paper reinvestigates the relationship(-s) between income inequality and democracy by employing models that adjust for the above-mentioned issues. Hence, it makes an empirical contribution to a field already rich in elaborate theoretical models. Section 2 briefly reviews arguments and results from the literature. Section 3 presents the data material and discusses 
salient methodological issues. Section 4 first presents empirical models that - like in most of the literature - assume one-way causal relationships. Thereafter, it reports more proper models accounting for endogeneity. There is no robust effect of income inequality, neither on democracy level, democratization probability nor democratic stability. In contrast, democracy seemingly reduces income inequality when the latter is proxied the share of income going to wages (see also Rodrik 1999). But, it does, for example, not reduce inequalities in disposable household incomes. There are some (nonrobust) indications that one-party dictatorships pursue more progressive redistributive policies than democracies.

\section{Arguments and results from the literature}

\subsection{Income inequality affects democracy}

At least since de Tocqueville, one prominent notion has been that "extreme disparities reduce the sense of community and legitimacy upon which democracy is supposed to rest" (Bollen and Jackman 1985, 440). In other words, high income inequality generates unfavorable conditions for democracy. Lipset (1959), for example, argues that democracy is less tenable in societies with high levels of social conflict, which in turn is generated by high inequality. A high concentration of economic resources may also undermine democracy, or at least the "quality of democracy" (Diamond and Morlino 2005), through increasing the concentration of political resources for example in terms of influence over legislators, the judiciary, and the media (see, e.g., Dahl 1989; Grossman and Helpman 2001; Przeworski 2010).

Political-economic models also suggest that income inequality affects regime type: Under democracy, the relatively poor median voter determines policy, preferring higher tax rates and more redistribution than rich voters (Meltzer and Richard 1981). In right-wing dictatorships, in contrast, the rich control government, inducing lower taxes and less redistribution. Hence, different social groups have clear preference-rankings over regime types, and income inequality may crucially affect the willingness (and the capabilities) of actors to fight for their favored regime. Despite these common assumptions, different political-economic models produce conflicting implications on exactly how inequality affects democratization prospects:

Boix (2003), for example, proposes a non-linear relationship, drawing on a model where there is asymmetric information on whether the rich elite is actually capable of suppressing the poor. Yet, lower inequality most often induces higher probability of democratization in Boix' model; the rich have less to lose from the poor determining tax rates in egalitarian societies. Rich elites therefore more easily agree to demands for democracy, without risking a fight, when inequality is low. In contrast, Acemoglu and Robin- 
son's (2000) model implies that higher inequality increases democratization chances. In unequal societies the poor have (particularly) much to gain from democratization, and the rich are unable to credibly commit to future redistribution under dictatorship. In a later study, Acemoglu and Robinson (2006) propose that the combination of lower demand for democracy and the higher willingness by elites to supply democracy in egalitarian societies - and the opposite in inegalitarian societies - generate a hump-shaped relationship between inequality and democratization probability. Yet, the above-discussed models all rely on potentially problematic assumptions, for instance that non-elite actors are able to solve collective action problems when challenging existing regimes (Kuran 1989; Houle 2009; Haggard and Kaufman 2012), or by failing to distinguish distinct elite groups with very different interests (Ansell and Samuels 2010). Thus, it remains unclear in what direction we would expect income inequality to affect democratization chances (and level of democracy), and how strong we should expect a potential link to be.

The evidence on the relationship between income inequality and democracy is then also mixed. Bollen and Jackman $(1985,1995)$ find no robust relationship, whereas Muller (1988, 1995), using alternative specifications, finds that high inequality reduces democratization probability. Boix (2003) and Boix and Stokes (2003) also report that low inequality induces democratization, using Gini coefficients on income inequality and the "Family Farms" measure from Vanhanen (1997). However, Ansell and Samuels (2010) find that whereas lower land inequality indeed enhances democratization prospects (see also Ziblatt 2008), lower income inequality may have the opposite effect. Yet, even the estimated impact of income inequality, more specifically, may depend on choice of measure; Przeworski et al. (2000) find that low income inequality induces democratization - but only when using wage and capital shares of income as proxies. Other recent contributions argue that the links between income inequality and democracy only operate under certain conditions - for example, in countries that are strongly integrated in the global economy and financial system (e.g., Freeman and Quinn 2012) - thus explaining the non-robust net relationship. Regarding democratic survival, Przeworski et al. (2000) and Houle (2009) report that high income inequality destabilizes democracies, although other studies fail to identify a clear relationship between high inequality and democratic reversals (Teorell 2010). Still, most these studies have in common is that they do not account properly for inequality perhaps being endogenous to regime type, and this may affect the reported results.

\subsection{Democracy affects income inequality}

To illustrate the above point, Houle - who proposes a democracy-stabilizing effect of low inequality - notes that "most stable democracies that are 
poor turn out to be very equal. Some examples include India, Costa Rica, Uruguay, Jamaica, Mauritius, Papua New Guinea, and Mongolia" (Houle 2009, 595). But, consider one of Houle's examples, Mauritius. This African island-state was quite inegalitarian at decolonization. Mauritian society was agrarian, with the most important export product being sugar produced on large plantations. The plantation owners - the "Grande Blanches" of European origin - constituted only 1-2 percent of the population, but accounted for much of national income. Democracy seems to have introduced pressures for redistribution, however: From 1965 to 1987 Mauritus' Gini coefficient was reduced from 0.50 to 0.37 , likely affected by redistributive polices promoted by the regime (Brautigam 1997, 58). Various democratic Mauritian governments expanded schooling opportunities and health-care access, and introduced progressive taxes. Furthermore, the regime spent tax revenue from sugar production on building up an effective textile sector, where poor women constituted a majority of workers. Hence, the proposition that democracy is stabilized by low inequality is, at best, only part of the Mauritian story.

Interestingly this interpretation of Mauritian history - emphasizing that democracy reduced inequality - is congruent with contributions to the theoretical literature on how inequality affects democracy. The main reason why inequality matters for democratization in the models of Boix and Acemoglu and Robinson is that both elites and non-elites consider democracy a vehicle for progressive redistribution. Acemoglu et al. (2013) finds that democracy increases the share of income going to taxes (but, see also Aidt and Jensen 2013), which might, in turn, be used for progressive redistribution. The authors also replicate the result that democracy increases (secondary level) education spending, which likely has progressive consequences (see also Saint-Paul and Verdier 1993; Lake and Baum 2001). Further, Lindert (2005) reports that the expansion of democratic participation rights induced higher social welfare spending and widened access to education in 19th century Europe, thus contributing to reduced inequality.

However, democratization processes of later decades have not been characterized by gradual expansion of participation rights in previously oligarchic regimes, but rather by transitions from various regimes without competitive elections towards democracies with formal participation rights for all citizens (Miller 2014). The predicted effects on inequality from such transitions are not as clear cut, and depend, for instance, on the type of dictatorship prior to democratization. Single-party regimes with winning coalitions drawn from the working classes might produce more extensive redistribution than democracies (e.g., Boix 2003; Acemoglu and Robinson 2006). Indeed, the survey in Gradstein and Milanovic (2004) indicates that there may be a more pronounced effect of franchise expansion than of other democratiza-tion-related processes on inequality. The considerations above could contribute to explain why Mulligan et al. (2004), employing data from 
1960-1990, find no robust effect of democracy on a range of redistributive policies (see also, e.g., Cheibub 1998).

More generally, democratic politics does not necessarily follow the "distributional-game" pattern of the models by Boix and Acemoglu and Robinson, but is often more complex with multiple issue dimensions and classcutting alliances (e.g., Bollen and Jackman 1985; Ansell and Samuels 2010). Further - as detailed in a large political science literature on democracy in developing country contexts (e.g., Chabal and Daloz 1999), and recently highlighted by Acemoglu et al. (2013) and Albertus and Menaldo (2014) a de jure democracy may be congruent with de facto concentration of power in the elites' hands, leading to "captured democracy" with little redistribution..$^{1}$ Finally, autocracies may not behave as in standard political economic model either; autocracies differ in terms of their institutional make-up and other characteristics, and several autocratic regimes have strong reasons to pursue redistributive policies to remain in power (Bueno de Mesquita et al. 2003; Gandhi 2008; Magaloni 2006; Haggard and Kaufman 2008; Knutsen and Rasmussen 2014). Taking such factors into account may alter the expected redistributive effect of democracy.

Despite an uncertain effect on progressive transfers, democracy may affect inequality through other channels. For instance, democracy may reduce pre-tax income inequality through increasing wages for workers and reducing the income-share going to capital owners. Rodrik (1999) and Przeworski et al. (2000) find that democracy enhances wages partly because of higher productivity, but also because of higher income-shares for labor (but, see Acemoglu et al. 2013, Appendix A). One reason could be that democracies more strongly protect freedom of association (Møller and Skaaning 2013), leaving employees with better opportunities to organize and bargain for higher wages than under dictatorship (see Deyo 1998).

A number of empirical studies have found that democracy generates more egalitarian income distributions (e.g., Muller 1988; Li et al. 1998; Chong 2004). However, other studies indicate the relationship is inversely U-shaped, and several early studies find no robust effect (see Sirowy and Inkeles 1990; Gradstein and Milanovic 2004). Also the recent and methodologically solid study by Timmons (2010) finds no robust effect of democracy on income inequality. Yet, as for studies of how inequality affect regime type, most studies on how regime type affect inequality have failed to properly account for endogeneity biases, country- and time-fixed effects, and potential sample selection biases. These are all addressed below when empirically reinvestigating how democracy affects income inequality, and vice

\footnotetext{
${ }^{1}$ Interestingly, Acemoglu et al. (2013) also suggest that democracy may increase income inequality through promoting structural transformations to the economy (notably from agriculture to manufacturing), and through reducing barriers to entry for new entrepreneurs. This may, in turn, lead to larger market-induced inequalities in gross income, with a new group of citizens making a very good living under democracy.
} 
versa.

\section{Data and methodology}

Section 3.1 presents the data material and operationalizations, centering on the income inequality and regime type measures. Thereafter, Section 3.2 discusses salient challenges to studying the causal relationship between democracy and income inequality, focusing on reciprocal causality and related endogeneity biases, but also discussing sample selection issues.

\subsection{Measurement and data sources}

Most existing inequality indices lack extensive time series and many only cover a subset of countries globally. This is problematic, as lacking coverage reduces the precision of estimates and may induce sample-selection biases. For instance, despite the strenuous efforts underlying the World Income Inequality Database (WIID), its Gini coefficients are measured infrequently with irregular time intervals for most countries. Moreover, the data are heterogeneous regarding "the definition of income and income recipient, ... the proportion of the population covered, and the nature of the data collection procedure, which makes international comparisons exceedingly difficult" (Gradstein and Milanovic 2004, 521). Such variation in measurement methodology has consequences for the ranking of, and distance between, countries (Lambert 2001).

However, one inequality proxy with fairly extensive coverage is the share of total income allocated to wages, or "wage share" (WS). WS is constructed from INDSTAT2 data (UNIDO 2011) on manufacturing-sector incomes. The data cover 163 countries, with maximum time series from 1963-2008. A low WS is, in practice, often related to high income inequality; in most societies the relatively poor are wage-earners, and the few very rich draw income from rents to capital, land or other non-wage sources of income (Rogowski 2009). WS is perhaps particularly suitable for testing the relationships posited in the political-economic models discussed above that center on elite-citizenry income disparities and related group preferences over regimes:

"when the major conflict is between the rich and the poor, one variable that captures inter-group inequality is the share of labor income in GDP. The reasoning here is that, whereas the poorer segments of society obtain most of their income from labor, capital income (and sometimes land income) accrues largely to a smaller elite. Therefore, a high labor share corresponds to a low level of inter-group inequality when conflict is between rich and poor" (Acemoglu and Robinson 2006, 59).

There are, however, legitimate criticisms of WS as a measure of inequal- 
ity (Timmons 2010), and the analysis below therefore also tests other inequality measures. First, WS relates to how gross income is distributed (between capital and labor) before taxation and government transfers. Since such policies may be endogenous to regime type, models using WS may generate biased results if inequality is conceptualized in disposable-income terms. Furthermore, WS only uses manufacturing-sector data, and does not consider distribution of tertiary sector income. WS also leaves out income distribution among landowners, peasants and agricultural workers, which may relate to democratization prospects (Ansell and Samuels 2010; Ziblatt 2008). Finally, WS does not separate between payments to, for instance, manual laborers and CEOs (Timmons 2010); a high score could reflect high salaries for the latter.

Hence, using more conventional Gini coefficients have some benefits. Gini coefficients are based on calculations of the cumulative income (or consumption) of citizens (or households) - ranked according to personal income - as shares of national income (see Lambert 2001). However, there is far more missing for most Gini measures - even in the extensive World Income Inequality Database (WIID) (UNU-WIDER 2008) gathering data from numerous sources, notably including the Deininger and Squire dataset than for WS. Second, the comparability of Gini estimates between different surveys is often questionable. WIID includes Gini coefficients measuring the distribution of income and of consumption and includes both grossand disposable income estimates. Third, the survey-based data - sometimes from specific regions within a country - may be associated with unsystematic and systematic measurement errors.

Various solutions have been implemented to deal with the above problems. Gerry and Mickiewicz (2008), for instance, employ rules for selecting only comparable, high-quality Gini estimates from WIID, when investigating the determinants of income inequality in 24 post-communist countries. They, e.g., first exclude consumption-based Ginis and data not stemming from representative samples, before employing rules on preferred definitions, sources, and methodologies. Below, I run robustness tests on Gini coefficients extracted from WIID2c using a resembling, although not as detailed, approach: First, observations are kept only if the income sharing unit is a household, family or tax unit. Second, observations are kept only if the income definition relates to net/disposable income. Third, only equivalencescale adjusted observations are kept. 1982 Gini observations remain, but many are from identical country-years; in such instances, the country-year score is the average of the remaining Ginis. Another approach to obtaining comparable Gini estimates is pursued by Galbraith and Kum (2005), who estimate Gini coefficients from a regression on Deininger and Squire high quality Gini coefficients with measures of manufacturing pay inequality, manufacturing employment to population, and dummies for Deininger and Squire data sources as independent variables. Below, also this Gini measure 
is used for robustness testing, and so is the Gini measure from the World Development Indicators (WDI).

However, in addition to models using WS, the below discussion centers on tests using Gini coefficients from the Standardized World Income Inequality Database (SWIID; Solt 2009) Version 3.1. Solt draws on the various, but not directly comparable, Gini coefficients in the WIID, and employs a more complex missing-data algorithm to standardize the information. The Luxembourg Income Study is chosen as basis for the standardization, due to its high quality and comparability of estimates across countries. Solt then follows a careful procedure that allows maximizing coverage and precision of estimates, while still ensuring comparability (see Solt 2014). Importantly, Solt constructs separate estimates for market- and disposable household income inequality.

Table 1 - Descriptive statistics on measures of income inequality

\begin{tabular}{lccccc}
\hline Inequality measure & Obs & Mean & Std. Dev. & Min & Max \\
\hline Wage share & 3471 & 36.66 & 14.31 & 1.67 & 140.94 \\
SWIID market income Gini & 4035 & 44.65 & 9.13 & 17.59 & 77.97 \\
SWIID disposable income Gini & 4100 & 38.19 & 10.52 & 15.39 & 71.33 \\
Galbraith and Kum Gini & 3249 & 40.70 & 7.02 & 19.81 & 64.36 \\
WDI Gini & 768 & 42.61 & 10.14 & 20.96 & 74.33 \\
WIID extracted disp. househ. Gini & 1060 & 36.20 & 10.77 & 16.63 & 63.18 \\
Top 1\% income share & 809 & 8.65 & 3.11 & 2.65 & 21.30 \\
\hline The statistics are reported for all observations in the dataset.
\end{tabular}

Table 1 reports descriptive statistics for the various inequality measures, and Table 2 reports their bivariate correlation coefficients. As Table 1 shows, the measures vary greatly in terms of coverage. Whereas WS and the Gini measures that invoke some form of prediction/multiple imputation model for generating scores (Galbraith and Kum and SWIID) cover around 3-4000 observations, the other measures cover about 1000 observations or less. However, only WS incorporates a very extensive number of "observed" datapoints. Further, Table 2 shows that there is, most often, only a modestly strong correlation between the measures. WS correlates most strongly with the WIID extracted Ginis (-0.56), whereas the absolute value of the correlation with the other Gini measures is lower than 0.4. The various Gini coefficients display bivariate correlations, with each other, ranging from 0.42 to 0.94 .

Another fascinating - and widely acknowledged (particularly after the publication of Piketty 2014) - effort to collect comparable measures of income inequality relates to the World Top Incomes Database, which provides different variables on share of income going to the top (or bottom) $X$ percent of income earners. While these measures are easy to interpret, the database currently covers less than 30 countries, many of which are high-income OECD countries. Thus, these data are only used for validation testing: One concern with WS is that it may be becoming a poorer proxy 
Table 2 - Bivariate correlation coefficients for various inequality measures

\begin{tabular}{|c|c|c|c|c|c|c|c|}
\hline & Wage share & Disp. Solt & Market Solt & $G \& K$ & WDI & WIID & Top $1 \%$ \\
\hline Wage share & $1(3471)$ & & & & & & \\
\hline Disp. inc. Gini (Solt) & $-0.38(2683)$ & $1(4100)$ & & & & & \\
\hline Market inc. Gini (Solt) & $-0.08(2630)$ & $0.76(4035)$ & $1(4035)$ & & & & \\
\hline Galbraith and Kum Gini & $-0.39(2793)$ & $0.69(2390)$ & $0.52(2326)$ & $1(3249)$ & & & \\
\hline WDI Gini & $-0.29(410)$ & $0.91(716)$ & 0.79 (716) & $0.42(263)$ & 1 (768) & & \\
\hline WIID extr. Gini & $-0.56(787)$ & $0.94(999)$ & $0.61(999)$ & 0.77 (617) & $0.93(365)$ & $1(1060)$ & \\
\hline Top $1 \%$ income share & $-0.54(578)$ & $0.61(666)$ & $0.31(666)$ & $0.47(498)$ & $0.81(51)$ & $0.72(249)$ & $1(809)$ \\
\hline
\end{tabular}

Note: The bivariate correlation coefficients are reported for all observations in the dataset with data on the two inequality measures in questions. Number of country-year observations in parenthesis.

of overall inequality over time, particularly in more developed countries, since it draws data from the manufacturing sector only; many countries are transitioning to post-industrial, service-intensive economies. Nevertheless, inequalities in the manufacturing sector might still correspond fairly closely with inequalities in other sectors, and WS would then perform decently as an (overall) inequality proxy. Figure 1 displays the time trend in the bivariate correlation coefficient between WS and share of income going to the top $1 \%$ income earners. The two graphs in Figure 1 - one for all countries with data and one only for OECD countries - show that the correlation has been consistently negative (as expected), but has varied in strength over time. While the correlation was weaker in the 1980s than in the 1960s and 70s, it has actually turned much stronger from 1990 onwards (see Figures A.1 and A. 2 in the Online Appendix for top 5 and 10 percent income measures). Hence, WS does not seem to become a poorer proxy for overall inequality over time, even as the manufacturing sector shrinks, at least in many rich OECD countries.

The widely used Polity Index (PI) is the baseline democracy measure. PI goes from -10 to 10 (most democratic), and incorporates indicators on competitiveness and openness of executive recruitment, competitiveness and regulation of participation, and checks on the chief executive (Marshall and Jaggers 2002). The PI thus covers different components of the democracy concept. However, 'political inclusiveness' is insufficiently accounted for (Munck and Verkuilen 2002; Gates et al. 2006). Given the above-noted theoretical focus on political inclusiveness - particularly related to suffrage rights - tests are also conducted employing the Scalar Index of Polities (SIP) index from Gates et al. (2006). SIP combines various Polity indicators with Vanhanen's Participation indicator measuring share of the population participating in elections. Other tests use the Freedom House Index (FHI). FHI has several validity and reliability problems, but incorporates subjective indicators on how political institutions function in practice (e.g., Munck and Verkuilen 2002) ${ }^{2}$ Nominally democratic institutions may not ensure the implementation of redistributive policies (e.g., Przeworski 2010; Acemoglu et

2 One particular problem with the FHI in this setting, is that at least 1 of its 25 indicators is, arguably, conceptually related to income inequality ("Is there equality of opportunity and the absence of economic exploitation?"), generating an a priori relation. 
Figure 1 - Bivariate correlation coefficients, by year, between share of income going to wage earners in manufacturing sector (WS) and share of total income going to top $1 \%$ income earners.
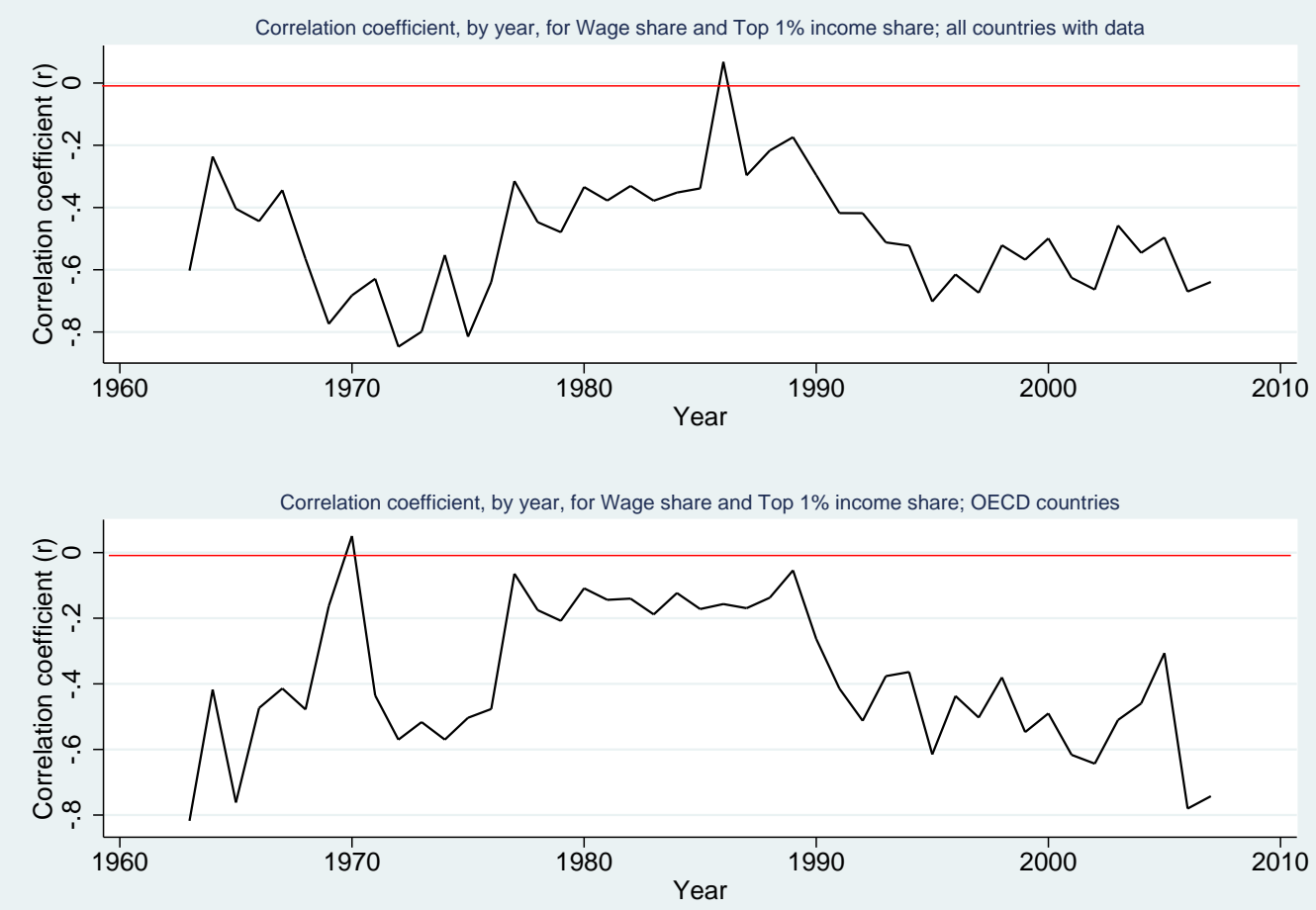

Notes: The top graph displays correlation coefficients from all countries with data (minimum 6, maximum 18 for particular years) and the bottom graph for OECD countries with data (minimum 5, maximum 11).

al. 2013), and de facto protection of political and civil rights may be more relevant for distributional outcomes. Finally, tests are also reported for the Democracy-Dictatorship (DD) measure from Cheibub et al. (2010) and Unified Democracy Scores from Pemstein et al. (2010). Table A.1 in the Appendix presents descriptive statistics for the various democracy measures and Table A.2 in the Online Appendix reports their pairwise correlations.

There is a positive and moderately strong correlation between WS and PI (.32; 3317 country-year obs.). However, this correlation could stem from other variables systematically affecting both regime type and income inequality. The regression models below therefore include several controls: First, they include (log) PPP-adjusted real GDP per capita (p.c.) from Maddison (2007), measured in 1990 USD. The relationships between income level and inequality (Kuznets 1955) and between income level and democracy (Przeworski et al. 2000) may, however, be non-monotonic, and the models therefore also controls for log GDP p.c. squared. Moreover, an economy dominated by natural-resource extraction may stabilize dictatorships (Ross 2001) and increase income inequality (Leamer et al. 1999). Hence, the models control for log (oil and gas income p.c. +1 ) using data from Ross (2011). They also control for log population level from Maddison (2007), and 
for $\log$ (regime duration+1), based on Polity IV data, since political instability may relate both to regime type and distributional aspects (Alesina and Perotti 1996). Table A.3 in the Online Appendix reports descriptive statistics for these variables.

\subsection{Pertinent methodological issues when investigating the causal links between democracy and inequality}

Different factors may generate a correlation between democracy and inequality, and need to be accounted for when investigating potential causal effects. In addition to the control variables listed, most models below control for country- and year fixed effects. However, there is another pertinent concern: As indicated by the review above, democracy may both cause and be affected by income inequality. Estimating these effects without accounting for endogeneity therefore likely leads to biased results. The few studies that explicitly model the democracy-inequality relationship as reciprocal draw on limited data and have generated quite mixed results. Rubinson and Quinlan (1977) include 32 countries with data from 1965-1975, finding that inequality enhances democracy, whereas democracy does not affect inequality. Bollen and Jackman (1985) include 60 countries, with inequality measured once during 1958-1975; they find no robust effect in either direction. Burkhart (1997) uses data from 56 countries for four points in time. ${ }^{3}$ His results indicate that improvements in democracy increase inequality at low democracy levels, but reduce inequality at high democracy levels. Likewise, modest income inequality generates the best prospects for democracy. The above-mentioned studies rely on instrumental-variable approaches, but their choices of instruments may have generated biases. ${ }^{4}$

Therefore, different models accounting for endogeneity biases are employed below, drawing on data for about 3000 observations from 120 countries. The first such specifications are fixed effects two stage least squares (FE2SLS) models. For studying the causal effect of democracy on inequality, two valid instruments - i.e. measures correlated with the endogenous independent variable, but not directly related to the dependent - are identified: The first instrument, WAVE, has previously been applied in analyzing democracy's effects on property rights and economic growth (Knutsen 2011a,b). WAVE is based on Huntington's (1991) observation that democracy, globally, has thrived in temporal waves, with set-backs during "reversewaves". The waves reflect sources of regime-type variation exogenous to

\footnotetext{
${ }^{3}$ For a relatively similar analysis, see Burkhart (2007).

4 Burkhart, for instance, uses many of the same instruments in the first stages of both the democracy and inequality models. As the exclusion restriction, somewhat simplified, states there should be no direct effect of the instruments on the dependent variable in the second-stage equation, this is problematic. It is, for example, inconsistent to assume energy consumption is a proper instrument for democracy in the inequality model, and then assume they are unrelated in the democracy model.
} 
domestic economic outcomes, as they proxy for changes in the internationalpolitical environment affecting democracy prospects and spill-over effects from regime changes abroad. WAVE is scored 1 where the reigning regime originated within the (reverse-wave) periods $\langle, 1827]$, [1922, 1942], [1958, 1975], [1998, 2003], and 0 otherwise. RPRI, which was constructed to investigate democracy's effect on different types of inequality (Huber et al. 2011), is the second instrument. RPRI also uses the international context as source of exogenous variation, taking the current regime's inception date as point of departure. RPRI records average Polity-score of other countries in the geographic region at the date of the country in question's last regime change.

These instruments correlate very strongly with current regime type, and there is little theoretical reason - and this is also clearly supported by overidentification tests presented below - to fear that they are directly related to inequality (when controlling for all the covariates). In contrast, I have been unable to identify any instrument for income inequality both satisfying the "strong instrument" criterion and the exclusion restriction. 5 Thus, one needs a different strategy to investigate how inequality causally affects regime type.

The empirical analysis therefore contains different GMM models that treat inequality as an endogenous regressor to investigate the latter effect. It also presents GMM models for investigating the effect of regime type on inequality - then with regime type as endogenous regressor. The GMM models include Arellano-Bond, or difference GMM, models, which use lags of levels as instruments for the first-differences of the endogenous regressors (Arellano and Bond 1991). Despite its many beneficial properties, ArellanoBond models perform sub-optimally for slow-moving variables, such as democracy and inequality. Blundell and Bond (1998), using Monte Carlo simulations, show that system GMM models - which augment the ArellanoBond instrumentation strategy for endogenous regressors by also instrumenting for levels with lags of differences - perform better in such contexts. Hence, the analysis below reports system GMM models as well.

Different GMM specifications are tested and evaluated on the basis of relevant diagnostics tests (see, e.g., Roodman 2009a), notably Arellano-Bond $\operatorname{Ar}(\mathrm{x})$ autocorrelation tests and Hansen-J tests for overidentifying restrictions. Arellano-Bond $\operatorname{Ar}(2)$ autocorrelation tests, for example, often indicate that models with inequality as dependent variable should include two lags of the dependent as regressor, whereas one lag is sufficient for models

5 Acemoglu et al. (2008) use lagged savings rates as instrument when investigating the impact of income level on democracy. I tested both 5- and 10-year lagged savings rates as instruments for inequality - the 'Kaldor Hypothesis' proposes that rich capital owners save higher shares of their incomes; savings rates and inequality might thus correlate. Yet, while overidentification tests indicate the exclusion restriction holds, savings rates turn out to be very weak instruments. Hence, such FE2SLS models unsurprisingly fail to identify any significant effect of inequality on democracy, this is actually in line also with the more credible GMM results presented below. 
having democracy as dependent. Following Roodman (2009b), most models below restrict the number of lags used for instrumentation to reduce the overall number of instruments. Having substantially more instruments than cross-section units may lead to failure to exclude the endogenous component of the instrumented regressors and difficulties in detecting this through standard (Hansen J) tests.

The initial analysis is conducted on panel data where country-year is the unit of analysis, thus including around 3000 country-year observations. However, these models are complemented by running otherwise equivalent models on 5-year panel periods, as is common, for example, in the economic growth literature. The former has the advantage of increasing efficiency of estimates by including more information. It also allows for more appropriately capturing effects if they operate with a short time-lag. However, the latter approach also has advantages. First, both regime type and income inequality are, as noted, both slow-moving variables, and capturing short-term dynamics may thus not be as important as smoothing out random measurement errors by averaging over multiple years. This approach may also partly alleviate endogeneity concerns, if the independent variable is measured early in the 5-year panel, or if one lags the independent variables by one panel unit (as below). Increasing panel length also reduces the number of instruments in the GMM models and thus mitigates the "toomany-instruments problem" (Roodman 2009b). Finally, averaging over 5year periods alleviates problems with missing data, which is particularly pertinent for many of the Gini measures, if one does not require coverage for every year in the panel to provide a score. It should, however, be noted that one underestimates the uncertainty inherent in the scores by doing this, as short-term fluctuations and measurement errors in particular years become more influential. But, there are other ways of dealing more systematically with missing data:

Despite having far better coverage than most other inequality data sources, INDSTAT2 and SWIID still contain a substantial amount of missing. This generates less reliable coefficient estimates. But, what is far worse, the data may not be missing at random, and omitting these observations could produce biased coefficients. For example, if most democracies, but only dictatorships with strong concerns for redistribution, report data, one might underestimate the effect of PI on WS. Inspection of the data substantiates concerns of sample-selection biases. For example, whereas the average (0-100 normalized) PI score for observations with WS data is 63 , it is 42 for those missing WS data. Furthermore, the average GDP p.c. (1990 USD) for country-year observations with WS data is 7147, and only 3558 for those missing data. Hence, multiple imputation was employed to predict missing values, using Amelia II software (Honaker and King 2010). The results reported below draw on 10 imputed datasets, reporting average coefficients and imputation-corrected errors. The datasets include 124 variables 
- selected because they are anticipated to be informative predictors of inequality or regime type, and have fairly good empirical coverage (see Figure A.4 in the Online Appendix for a missingness map). The datasets include 184 countries with maximum time series from 1960-2008. The imputationalgorithm assumes second-order polynomial, country-specific time trends.

The imputation model performs fairly well, as illustrated by the overimputation plot for WS (Figure A.4), showing how the imputation model is able to accurately "predict" actual scores on WS - except for the very highest scores - when treating them "as if" they were missing. Also time-series plots (such as Figure A.6 in the Online Appendix) suggest that the imputation model mostly produces sensible predictions.

\section{Empirical analysis}

Section 4.1, presents "naive" baseline models on how inequality affects regime type and on how regime type affects inequality. As in most of the empirical literature, these models do not account for endogeneity biases. Section 4.2 then employs more appropriate model specifications investigating the effect of inequality on regime type. Finally, Section 4.3 reports more appropriate specifications for investigating how regime type affects income inequality.

\subsection{Baseline models}

Table 3 shows models with regime type, measured by PI, as dependent variable (henceforth "democracy models"), and models with income inequality, proxied by WS, as dependent variable ("inequality models"). WS measures income share going to wages in percent, and PI is also normalized to vary from $0-100$. This normalization does not affect the $t$-values, but eases comparisons of the size of the estimated effects (of democracy on inequality and vice versa) by setting WS and PI to equivalent scales. The baseline models are Ordinary Least Squares with Panel Corrected Standard Errors (OLS PCSE) (see Beck and Katz 1995). Initially, country-year is unit of analysis, independent variables are lagged one year, and errors are adjusted for panel-level heteroskedasticity and AR(1) autocorrelation within panels (countries). The baseline democracy and inequality models are, respectively:

$$
\begin{aligned}
P I_{i, t} & =\beta_{0}+\beta_{1} W S_{i, t-1}+\beta_{2} G D P_{i, t-1}+\beta_{3} G D P S Q_{i, t-1}+\beta_{4} O I L I N C_{i, t-1} \\
& +\beta_{5} P O P_{i, t-1}+\beta_{6} R E G D U R_{i, t-1}+\epsilon_{i, t} \\
W S_{i, t} & =\beta_{0}+\beta_{1} P I_{i, t-1}+\beta_{2} G D P_{i, t-1}+\beta_{3} G D P S Q_{i, t-1}+\beta_{4} O I L I N C_{i, t-1} \\
& +\beta_{5} P O P_{i, t-1}+\beta_{6} R E G D U R_{i, t-1}+\epsilon_{i, t}
\end{aligned}
$$

The results from these naive baseline models (AI and AIV) are presented in Table 3. The models contain around 3000 observations from 120 countries, 
Table 3 - Baseline models, and models accounting for year- and country-specific effects

\begin{tabular}{|c|c|c|c|c|c|c|}
\hline Ind.var. \Dep.var. & $\begin{array}{c}\text { AI } \\
\text { PCSE } \\
\text { Polity } \\
b /(t)\end{array}$ & $\begin{array}{c}\text { AII } \\
\text { PCSE } \\
\text { Polity } \\
b /(t)\end{array}$ & $\begin{array}{c}\text { AIII } \\
\text { FE } \\
\text { Polity } \\
b /(t)\end{array}$ & $\begin{array}{c}\text { AIV } \\
\text { PCSE } \\
\text { Wage share } \\
b /(t)\end{array}$ & $\begin{array}{c}\text { AV } \\
\text { PCSE } \\
\text { Wage share } \\
b /(t) \\
\end{array}$ & $\begin{array}{c}\text { AVI } \\
\text { FE } \\
\text { Wage share } \\
b /(t)\end{array}$ \\
\hline Wage share & $\begin{array}{c}0.086^{* * *} \\
(2.86)\end{array}$ & $\begin{array}{c}0.185^{* * *} \\
(4.76)\end{array}$ & $\begin{array}{l}0.237^{* *} \\
(2.46)\end{array}$ & & & \\
\hline Polity & & & & $\begin{array}{c}0.046^{* * *} \\
(3.69)\end{array}$ & $\begin{array}{c}0.053^{* * *} \\
(4.55)\end{array}$ & $\begin{array}{c}0.064^{* * *} \\
(2.91)\end{array}$ \\
\hline Ln GDP p.c. & $\begin{array}{c}19.442 \\
(0.92)\end{array}$ & $\begin{array}{c}33.533^{*} \\
(1.66)\end{array}$ & $\begin{array}{c}88.519^{* *} \\
(2.05)\end{array}$ & $\begin{array}{c}-37.153^{* * *} \\
(-4.06)\end{array}$ & $\begin{array}{c}-16.391^{* *} \\
(-2.53)\end{array}$ & $\begin{array}{c}-27.788 \\
(-1.22)\end{array}$ \\
\hline Ln GDP p.c. sq. & $\begin{array}{l}-0.025 \\
(-0.02)\end{array}$ & $\begin{array}{l}-1.242 \\
(-0.99)\end{array}$ & $\begin{array}{c}-5.230^{*} \\
(-1.96)\end{array}$ & $\begin{array}{c}2.461^{* * *} \\
(4.41)\end{array}$ & $\begin{array}{c}1.068^{* * *} \\
(2.71)\end{array}$ & $\begin{array}{l}1.686 \\
(1.22)\end{array}$ \\
\hline Ln oil/gas inc. p.c. & $\begin{array}{c}-3.273^{* * *} \\
(-4.43)\end{array}$ & $\begin{array}{c}-0.955^{* *} \\
(-2.20)\end{array}$ & $\begin{array}{l}-0.030 \\
(-0.05)\end{array}$ & $\begin{array}{l}0.274 \\
(1.38)\end{array}$ & $\begin{array}{l}-0.242 \\
(-1.16)\end{array}$ & $\begin{array}{l}0.093 \\
(0.18)\end{array}$ \\
\hline Ln population & $\begin{array}{c}7.683^{* * *} \\
(4.92)\end{array}$ & $\begin{array}{l}0.452 \\
(0.27)\end{array}$ & $\begin{array}{l}-7.058 \\
(-0.55)\end{array}$ & $\begin{array}{l}-0.796^{*} \\
(-1.78)\end{array}$ & $\begin{array}{c}-0.774^{* *} \\
(-2.01)\end{array}$ & $\begin{array}{l}1.850 \\
(0.37)\end{array}$ \\
\hline Ln regime duration & $\begin{array}{c}-2.636^{* * *} \\
(-4.74)\end{array}$ & $\begin{array}{c}-2.648^{* * *} \\
(-5.22)\end{array}$ & $\begin{array}{c}-6.698^{* * * *} \\
(-4.83)\end{array}$ & $\begin{array}{l}0.232 \\
(0.96)\end{array}$ & $\begin{array}{l}0.158 \\
(0.69)\end{array}$ & $\begin{array}{l}0.013 \\
(0.03)\end{array}$ \\
\hline Ethnic fraction. & & $\begin{array}{l}0.378 \\
(0.05)\end{array}$ & & & $\begin{array}{l}-2.111 \\
(-0.87)\end{array}$ & \\
\hline E.Europe-Soviet & & $\begin{array}{c}-15.056^{*} \\
(-1.93)\end{array}$ & & & $\begin{array}{c}-7.666^{* * *} \\
(-3.58)\end{array}$ & \\
\hline S.S. Africa & & $\begin{array}{c}-26.334^{* * *} \\
(-2.66)\end{array}$ & & & $\begin{array}{c}-7.907^{* * *} \\
(-2.72)\end{array}$ & \\
\hline Asia & & $\begin{array}{l}-11.077 \\
(-1.50)\end{array}$ & & & $\begin{array}{c}-16.614^{* * *} \\
(-6.99)\end{array}$ & \\
\hline Middle E.-N.Afr. & & $\begin{array}{c}-49.771^{* * *} \\
(-7.09)\end{array}$ & & & $\begin{array}{l}-3.498 \\
(-1.26)\end{array}$ & \\
\hline Latin America & & $\begin{array}{l}-3.199 \\
(-0.31)\end{array}$ & & & $\begin{array}{c}-9.676^{* * *} \\
(-3.19)\end{array}$ & \\
\hline British colony & & $\begin{array}{c}12.773^{* * *} \\
(2.76)\end{array}$ & & & $\begin{array}{l}1.124 \\
(0.72)\end{array}$ & \\
\hline French colony & & $\begin{array}{l}-4.408 \\
(-1.08)\end{array}$ & & & $\begin{array}{c}4.180^{* *} \\
(2.46)\end{array}$ & \\
\hline Portuguese col. & & $\begin{array}{l}8.842 \\
(0.81)\end{array}$ & & & $\begin{array}{c}-8.790^{* * *} \\
(-3.07)\end{array}$ & \\
\hline Spanish colony & & $\begin{array}{l}1.578 \\
(0.19)\end{array}$ & & & $\begin{array}{c}-6.210^{* * *} \\
(-2.88)\end{array}$ & \\
\hline Belgian colony & & $\begin{array}{l}4.459 \\
(0.62)\end{array}$ & & & $\begin{array}{c}-13.858^{* * *} \\
(-5.57)\end{array}$ & \\
\hline Year dummies & & Y & $\mathrm{Y}$ & & $\mathrm{Y}$ & $\mathrm{Y}$ \\
\hline $\mathrm{N}$ & 3026 & 3011 & 3026 & 3031 & 3015 & 3031 \\
\hline Countries & 120 & 119 & 120 & 120 & 119 & 120 \\
\hline
\end{tabular}

Note: ${ }^{*} p<.10 ;{ }^{\star *} p<.05 ;{ }^{* \star *} p<.01$. T-values in parentheses. Wage share is dependent variable in Models Al-AIII and normalized Polity (0-100) in AIV-AVI. Errors in OLS PCSE models are adjusted for panel-specific $A R(1)$ autocorrelation and panel-level heteroskedasticity. Errors in fixed effects models are clustered by country. Year dummies and constant are omitted from table. Maximum time-series is 1964-2008 in Al-Alll and 1963-2007 in AIV-AVI. Independent variables are lagged one year.

which are listed in Table A.4. The two models show statistically significant "effects" at 1 percent, both of inequality on democracy and of democracy on inequality. Hence, if we are to believe these models, low income inequality enhances the level of democracy, and more democratic regimes induce lower inequality. However, the estimated size of the two "effects" are not very large. To illustrate, changing from a situation where 20 percent of total income goes to wages to a situation where 60 percent goes to wages expectedly increases PI by less than 4 percent of its total range, according to the 
point estimate in Model AI. This is not a substantial democratization. Regarding the effect of regime type on inequality, Model AIV indicates that the kind of democratization experienced in the Philippines with the fall of Marcos - from 30 to 90 on the PI - would increase the percentage-share of income going to wages with around 3.

The estimates in Models AI and AIV may, however, be affected by omitted variable bias. One concern relates to systematic time trends in income inequality (Rogowski 2009) and in regime characteristics (Huntington 1991). The baseline models are therefore expanded by including year-dummies. Also different geographical, socio-cultural, and political-historical factors, could impact on both regime type and inequality (Engerman and Sokolo 1997; Acemoglu et al. 2008). Thus, Models AII (democracy model) and AV (inequality model) also add the Ethnic Fractionalization Index from Alesina et al. (2003) and dummies for geographic region and historical colonizer. Still, there may be other consequential country-fixed characteristics, and Models AIII and AVI thus include both country- and year-dummies. Yet, controlling for time- and country-fixed characteristics does not weaken the estimated relationships between democracy and income inequality: The estimate from Model AIII, for example, indicates that an increase in WS from 20 to 60 increases PI by around 9.5 percent. Furthermore, a democratization akin to that in the mid-1980s Philippines (from 30 to 90) would, according to Model AVI, increase WS with about 4. Hence, the results in Table 3 suggest that democracy reduces income inequality, and that low inequality enhances the level of democracy. This is replicated also for similar models run on 5-year panels (Table A.6), and when controlling for education (Table A.7), although the significance is weakened for the "effect" of inequality on democracy in the latter models. Yet, these results are only preliminary: Despite controlling for country- and year-fixed effects, the models in Table 3 do not account for endogeneity biases.

\subsection{Further investigating how inequality affects democracy}

I first turn to scrutinizing the (potential) causal effect of inequality on regime type. The baseline models above suggested that lower levels of inequality lead to more democratic regimes. Yet, this is seemingly not the case according to most of the GMM Models with inequality as dependent variable, reported in the Online Appendix. These models draw on quite different specifications (e.g. 1-year versus 5-year periods as panel unit), data samples (only observed versus also including imputed data), and measures. Importantly, however, they all treat inequality as endogenous and account for both country- and year-fixed effects.

To be more specific, Table A.8 reports five Arellano-Bond and five System GMM specifications with country-year as unit of analysis, PI as dependent variable, and WS as the (endogenous) measure of democracy. These 
include models with one and with two lags of the dependent variable as regressors; models treating only WS as endogenous and models treating all regressors except the year dummies as regressors; and, models with different restrictions on lags used for instrumentation. 4 of these 10 models report a negative WS coefficient, whereas 6 report a positive. WS is always insignificant even at 10 percent, with one single exception. Furthermore, this exception - an Arellano-Bond model including one lag of WS as regressor and using only the second lag for instrumentation - is not appropriately specified, as indicated by the low p-value (0.02) on the Arellano-Bond $\operatorname{Ar}(2)$ autocorrelation test.

Indeed, only models including two lags of WS as regressors yield pvalues above 0.10 on the $\operatorname{Ar}(2)$ test. Two of these models - one ArellanoBond and one System GMM model - are reproduced as BI and BII in Table 4. These models are also associated with sufficiently high p-values on the $\operatorname{Ar}(3)$ and Hansen J-tests. Further, the number of instruments in BI is below the number of cross-section units, whereas it is slightly above in BII. Taken together, BI and BII should thus provide consistent results, and they report that changes in WS do not systematically affect PI. Hence, there are no clear indications that inequality systematically affects democracy once accounting for inequality being endogenous.

This (non-)result is fairly stable. For instance, it holds up in various twostep-GMM specifications (see Table A.9). However, due to the numerous time periods in the country-year panel set-up, it is difficult to model other regressors than PI as endogenous - at least while relaxing restrictions on lags used for instrumentation - without increasing the number of instruments far beyond the number of cross-section units. Thus, the Appendix contains several models where 5-year periods (starting with 1960-1964) are the panel units; the variables are provided their average score during the 5 -year period in question, and all independent variables are lagged one 5year period to further mitigate endogeneity concerns. These models mostly replicate the non-result from the 1-year specifications (see, e.g., Table A.10), with a few exceptions. One is Model BIII in Table 4, which is an ArellanoBond specification with two lags of the dependent variable (WS) as regressors, and modelling only PI as endogenous. In BIII, there is a weakly significant $(t=1.7)$ positive effect of WS on PI, but whereas the $\operatorname{Ar}(2)$ and Hansen J-test p-values (barely) exceed 0.10, the p-value for the $\operatorname{Ar}(3)$ test is 0.04 . In contrast, all the different test statistics indicate that Model BIV - where the entire set of regressors are endogenous, but only 3-5 lags are used for instrumentation - is consistent, and here WS is actually negative, but statistically insignificant $(t=-0.4)$. This result is reproduced in BV $(t=-0.3$ for WS), the System GMM version of Model BIII, although the test-statistics are more problematic for this model. In any case, there is no clear evidence that inequality systematically affects democracy according to the 5-year panel models either. 


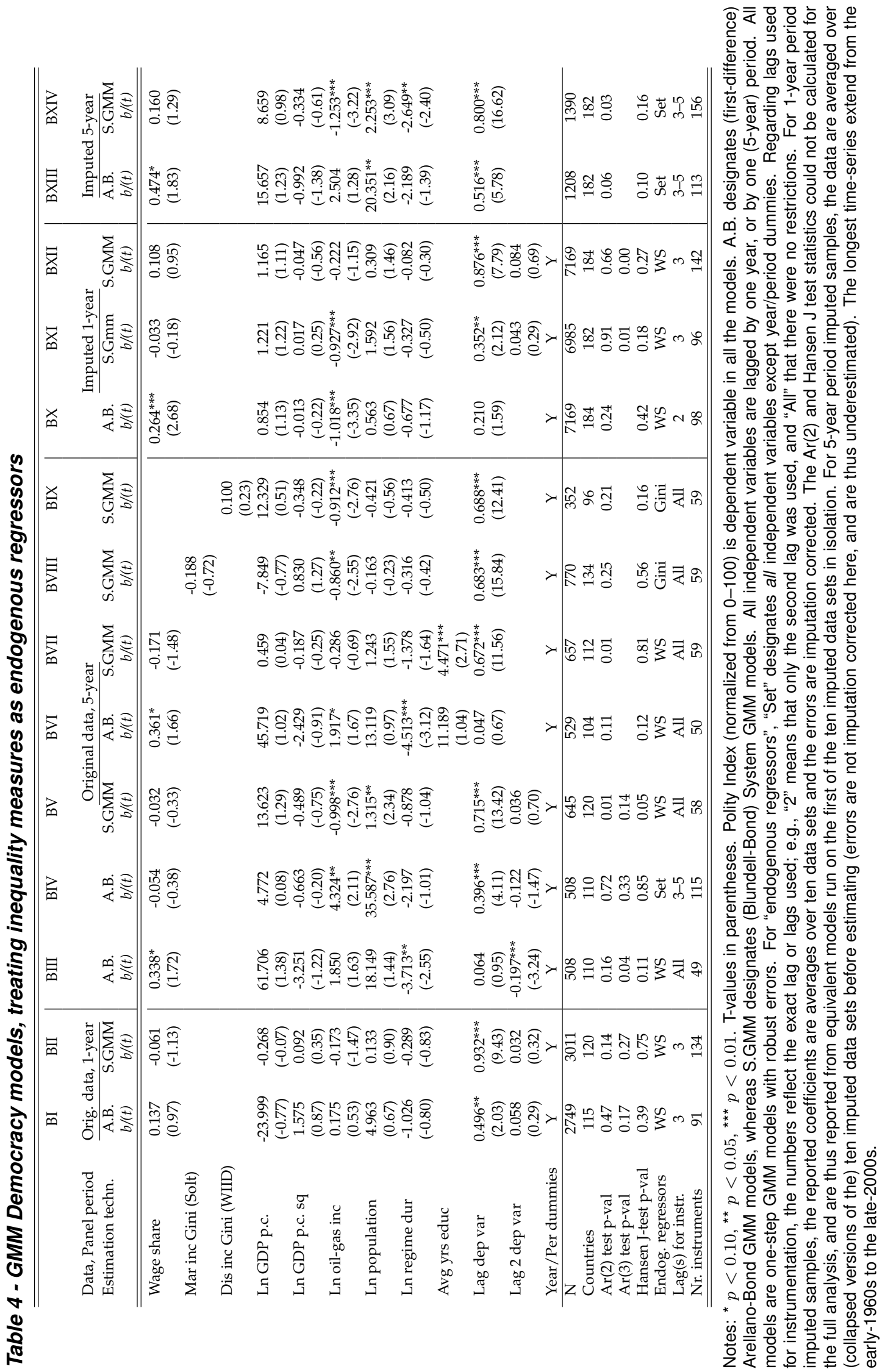

http://www.rei.unipg.it/rei/article/view/173 
The lack of a clear result holds true also, for instance, when making adjustments to the set of controls, such as adding average years of education in the population (above 25 years old), with data from the Barro and Lee dataset (see Barro and Lee 1993, results are reported in Models BVIBVII, Table 4 and Appendix Table A.12) ${ }^{6}$ The weak results may, however, be due to measurement problems with PI, or to PI not capturing relevant aspects of democracy. Casper and Tufis (2003) show how even highly correlated democracy measures give different results in regressions estimating the determinants of democracy. Models using (mean) Unified Democracy Scores from Pemstein et al. (2010) were therefore also tested. PI was also substituted with SIP (Gates et al. 2006), to check whether inequality impacts on a democracy measure incorporating differences in electoral participation. Moreover, high income inequality may negatively impact on the functioning of democratic institutions, for example through intensifying social conflict and increasing incentives for elites to subvert formally granted political and civil rights (e.g., Dreze and Sen 2002). Thus, inequality might be more strongly related with the FHI than indices measuring formal institutions. However, the lack of robust results is replicated when substituting the PI with either SIP, UDS or FHI (see Tables A. 19-21). The various GMM models were also modified by including squared WS-terms as endogenous regressors, to investigate whether intermediary levels of inequality induce democracy (e.g., Acemoglu and Robinson 2006). However, there is no evidence of such a hump-shaped relationship either.7 7

Despite these findings, two other methodological explanations could account for the lack of an estimated causal effect of inequality on regime type. The first relates to choice of inequality measure and data. The second relates to systematic missingness and resulting selection biases that may blur a potential net causal effect from being revealed in the GMM estimates. However, further investigation indicates that this is not the case:

First, WS was substituted with the various Gini measures. Gini coefficients arguably provide more direct measures of overall income inequality than WS, but collecting data and comparing Gini coefficients without limiting the number of observations too much, is complicated. As noted, the procedure and data provided by Solt (2009) constitute a very good attempt to resolve these issues. SWIID draws on standards set by the Luxembourg Income Survey, the rich data material in WIID, and multiple imputation models to produce comparable estimates of both market and disposable income inequality. If anything, the results are even weaker for the Solt measures, as illustrated by the system GMM models BVIII and BIX with the market

${ }^{6}$ It should, however, be noted that most models controlling for education level performs very poorly on the $\operatorname{Ar}(2)$ test, and may thus produce inconsistent results.

7 Actually, the squared WS-terms are positive and significant at 5 percent in two System GMM models in Table A.11. The point estimates indicate a negative marginal effect of WS on democracy for inegalitarian countries and a (weaker) positive marginal effect for very egalitarian countries. 
$(t=-0.72)$ and disposable $(t=0.23)$ income Ginis, respectively, as endogenous regressors ${ }^{8}$

Equivalent GMM models were also run using Gini indices from the other data sources. Models employing the Galbraith and Kum (2005) Gini, the WDI Gini, and Gini data extracted directly from the WIID on household disposable incomes (using the above-described algorithm) are reported in Tables A.16 - A.18. In general, the choice of inequality measure does not matter much; there is no clear net effect of income inequality on democracy. One exception relates to the System GMM specifications employing the extracted WIID Gini data: Four of five such models in Table A.18 show a statistically significant (at least 10 percent) Gini, and actually indicate that higher inequality increases democracy. Nevertheless, these models only draw on about 3505 -year period observations from around 95 countries, and all models may be affected by the too-many-instruments problem. In the System GMM model with fewer instruments than countries - which also produces acceptable p-values for the $\operatorname{Ar}(2)$ and Hansen tests - the effect is insignificant $(\mathrm{t}=0.45)$.

Second, the datasets generated by the multiple imputation model, described in Section 3.2, were employed. The null-result might stem from missing data reducing the precision of the estimates, or even generating biases. Whereas Models BI and BII contain around 3000 country-year observations, the models including imputed data exceed 7000 observations from more than 180 countries. The multiple imputation was conducted on the country-year version of the dataset, so calculating the appropriate imputation-corrected standard errors over the ten imputed datasets is only feasible for this format. This is therefore the baseline, but additional tests are conducted on a collapsed 5 -year period version. ${ }^{9}$

Some models including imputed data show support for the hypothesis that low levels of income inequality - at least when proxied by WS - induce more democratic regimes. More specifically, 3 of the 12 GMM specifications reported in Table A.37 show a positive and significant WS at 5 percent (whereas three other models show a negative, but insignificant WS). However, there are about 6 times as many instruments as countries in two of these specifications. The only appropriate specification - an Arellano-Bond model with one lag on the dependent variable and using only the second lag for instrumentation - is reported as Model BX in in Table 4. Here, the $\mathrm{t}$-value of WS is 2.7. However, System GMM specifications with relatively few instruments - and that perform well on the Hansen J-test and $\operatorname{Ar}(2)$ test (though not the $\operatorname{Ar}(3)$ test) - show no effect of WS. These models include

${ }^{8}$ For the Gini coefficients, high values indicate higher inequality; see also Tables A.14 and A.15.

9 For the latter, variable-scores are averages over the ten imputed datasets, and errors are not imputation corrected. Thus, these models underestimate the errors by failing to account for the data being imputed rather than observed (see, e.g., Honaker and King 2010). 
the two System GMM models reported as BXI and BXII in Table 4. There is some evidence that WS increases democracy also from the 5-year panel models (see Table Table A.39), although one should keep in mind that the standard errors here are not imputation corrected. However, this evidence is at best mixed - as suggested by contrasting the weakly significant coefficient in the Arellano-Bond Model BXIII with the statistically insignificant coefficient in the System GMM model BXIV. Furthermore, as Table A.38 reporting models using the Solt market income Gini illustrates, there are no indications of any effect when employing various Gini coefficients rather than WS. In sum, there is no robust evidence that low inequality induces democracy.

\subsubsection{Separating between effects on democratization and democratic sur- vival}

The lack of any robust effect of inequality on democracy level may, however, be due to inequality having quite different effects on democratization and on democratic stability. Making this distinction, Houle (2009) does not find that low inequality enhances democratization. However, he does find that low inequality stabilizes existing democracies. I reinvestigate this by - as Houle does - running dynamic probit models. Some specifications, employing the control variables from above, are reported in Table A.43. The table includes models using WS and the SWIID market income Gini as inequality measures, and different democracy measures: PI is dichotomized by classifying all country-years that score $\geq 6$ on PI (-10 to 10) as democracies, and I also employ the dichotomous DD, or ACLP, measure distinguishing democracies from dictatorships according to whether contested elections exist or not (Cheibub et al. 2010).

I tested different specifications - also other than those reported in Table A.43 - and neither the effect on democratization nor on democratic stability is robust. The models using DD and WS provide some indications that higher inequality spurs democratization, as suggested by Acemoglu and Robinson (2000). However, the result turns insignificant when exchanging either the democracy or the inequality measure. The more surprising finding, in light of the results in Houle (2009), is that the inequality-democratic stability relationship is also very sensitive. Houle uses WS as inequality measure and DD as democracy measure. My model using these measures, and including year-specific effects, replicates Houle's main result; lower inequality significantly (5 percent) enhances democratic stability. This result is also retained in the model including year-specific effects and using dichotomized Polity. Still, including year-specific effects on both democratization and democratic survival leads to serious collinearity issues and the sample being approximately halved. When excluding year-specific effects, there is no significant relationship between WS and democratic survival even at 10 percent. Furthermore, no model using SWIID Gini coefficients 
report anything close to significant effects on democratic survival 10

In sum, the main result in Houle (2009) - low inequality stabilizes democracies - is not robust. ${ }^{11}$. The findings above correspond well with those of Teorell (2010), who fails to identify any robust effect of income inequality on either democratic "upturns" or "downturns". Hence, the evidence is simply very weak for any (non-conditional) effect of income inequality on transitions to and from democracy.

\subsection{Further investigating how democracy affects inequality}

Rodrik (1999) finds that democracy enhances wages, but how robust is this relationship to accounting, for example, for endogeneity and sampleselection biases? The analysis below suggests it is fairly robust, although it does not hold across all plausible specification choices ${ }^{12}$ Nevertheless, there are indications that democracy increases the share of income going to wages. The evidence is far weaker when it comes to the link between democracy and inequality when the latter is measured by the various Gini coefficients.

The analysis includes both FE2SLS and GMM models, treating democracy as an endogenous independent variable. As already noted in Section 3.2, WAVE and RPRI are valid instruments for democracy in regressions where inequality is considered the effect-variable. This goes, for instance, for the FE2SLS Model CI in Table 5 with PI as democracy measure and WS as inequality measure: First, WAVE and RPRI are very strong instruments, as evidenced by first-stage $t$-values of, respectively, -17.8 and 21.9. The Sargan overidentification test also indicates the estimator is consistent $(p=0.32)$. Indeed, CI reports a positive significant effect (1 percent) of PI on WS. The estimated causal effect of "full democratization" on PI is a 6 point increase in the percentage-share of income going to wages. Although not robust to the choice of inequality measure (see Table A.22), the positive causal effect holds up when using different democracy measures, as illustrated by CII employing UDS $(t=3.1$; Sargan $p=0.28) \sqrt{13}$ Also when substituting WS with

${ }^{10}$ This non-result is even clearer when including imputed data to account for sample selection biases. This is, for instance, clear from Table A.44, but the non-robust link between inequality and democratic survival has also been replicated for different model specifications and datasets based on other imputation models for previous working paper versions.

${ }^{11}$ Furthermore, the dynamic probit models presented here and in Houle (2009) do not account for the endogeneity of inequality. I tried out different instrumental variables dynamic probit models, but they did not converge.

12 This is also demonstrated by Acemoglu et al. (2013, 44-46), who report that Rodrik's results are not completely robust when employing models more closely resembling Rodrik's original specification.

${ }^{13}$ I also tested a Treatment-Effects selection model (Greene 2003, 787-789), applying the dichotomous DD measure. In the first-stage equation, DD is considered a function of the controls, RPRI and WAVE. This model indicates that democracy - also when measuring 
the disposable income Gini from Solt (2009) in Model CIII, there are indications of democracy reducing income inequality $(\mathrm{t}=-1.9$; Sargan $\mathrm{p}=0.78)$.

Also the baseline GMM models run on the country-year panels mostly report a positive and significant PI when WS is the dependent variable (see Table A.23) ${ }^{14}$ Some of these models also seem well-specified according to the Ar- and Hansen J-test statistics. For example, Model CIV is an ArellanoBond model including only one lag of WS as regressor, with an Ar(2)-test pvalue of 0.32 , Hansen p-value of 0.20 , and fewer instruments than countries. PI is significant at 10 percent, and the estimated short-term effect of full democratization is a 7.6 point increase in WS. When accounting for multiplier effects via the lagged dependent variable, the estimated long-run effect is a substantial 10.5 increase in the share of total income going to wages. In the equivalent System GMM model (CV), the effect is significant at 1 percent. Here, the estimated short-term effect of full democratization is lower (5.7), but the long-term effect is higher (20.4). To illustrate, the latter is substantially larger than even the difference in WS scores (14.3) between Sweden and the (far more inegalitarian) US in year 2000.

The results are somewhat more mixed, but still point in the same direction, when employing 5-year panels. Table A.25 reports 12 different Arellano-Bond and System GMM specifications, for instance varying the number of lags used for instrumentation and varying whether only PI or the whole set of regressors are considered endogenous. All 12 models show positive PI coefficients, ranging from $0.02-0.11$, and 6 (7) of these coefficients are significant at $5(10)$ percent. Two of these models are also reported, as CVI and CVII, in Table A.5 ${ }^{15}$ As shown in the Appendix, this pattern (a positive effect of democracy on WS that is often significant, but not robust), holds up also in two-step models and models using different democracy measures on the 5-year panels. Further, the results are quite similar, although slightly weakened, when also controlling for education (see Table A.27). This is exemplified by Model CVIII, which controls for average years of education for the adult (25+ years) population with data from Barro and Lee. The point estimate is fairly high (0.088), but the t-value is only 1.616

only its contestation component - reduces income inequality (p-value=.003). Going from dictatorship to democracy is estimated to increase WS by 10.7 .

${ }^{14}$ Two-step versions of these GMM models more often generate insignificant results, but the point estimates are fairly sizeable and similar to those in one-step models (see Table A.26).

${ }^{15}$ Yet, it should be noted that the $\operatorname{Ar}(2)$ test p-value for Model CVII is very low.

${ }^{16}$ Nevertheless, controlling for education may take out an important channel through which democracy reduces inequalities, potentially inducing post-treatment bias. Democratic regimes may incentivize politicians to provide broad-based education systems, and not only elite education, to please large groups of voters, as theorized in various contributions (Saint-Paul and Verdier 1993; Lake and Baum 2001) and identified in empirical contexts such as 19th century Europe (Lindert 2005) and post-colonial Africa (Stasavage 2005). This might provide lower-income citizens with the requisite human capital to increase their productivity and wages, potentially also reducing aggregate inequality. 


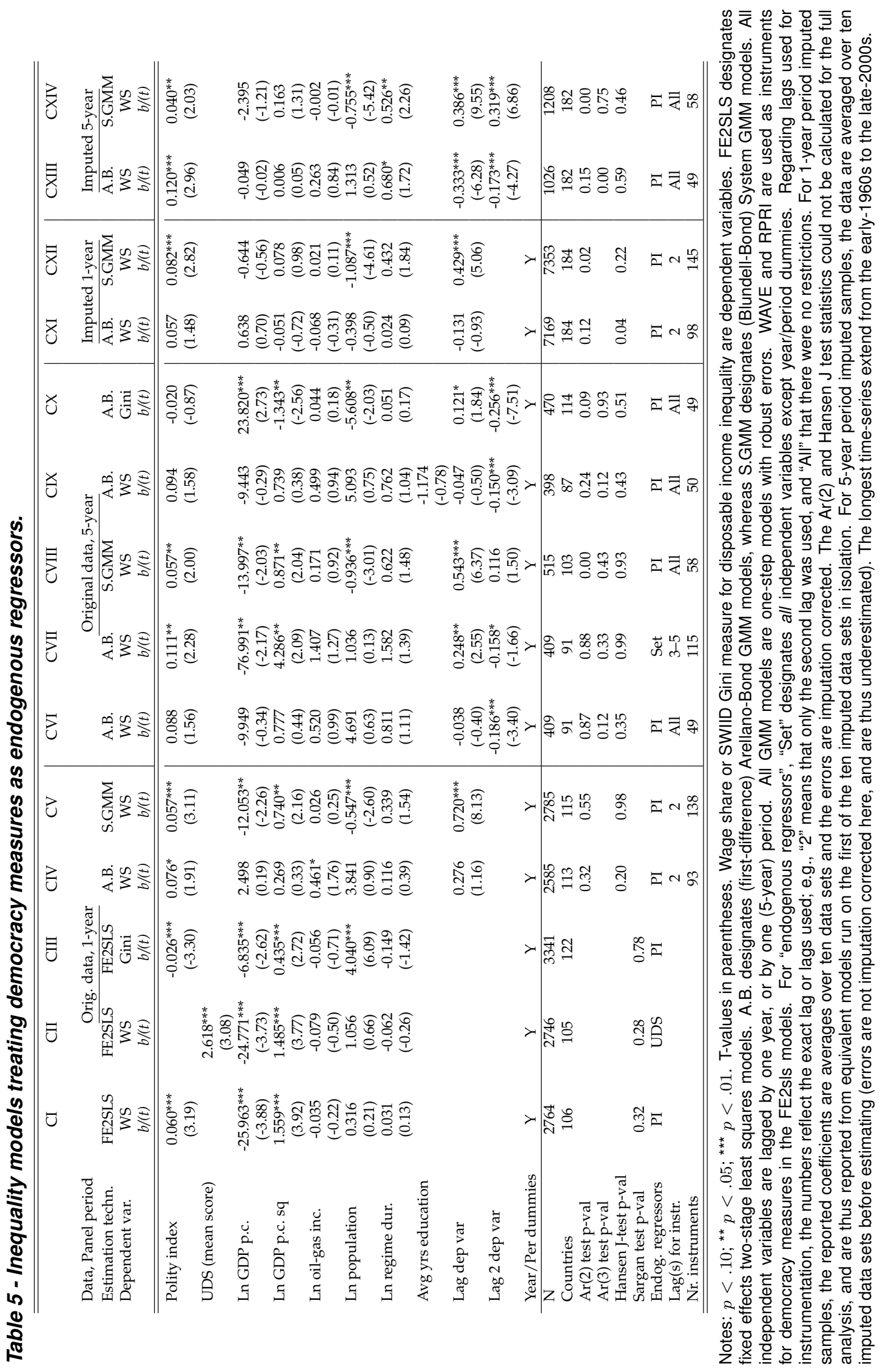


The results for the 1-year (Table A.40) and 5-year panels (Table A.42) also mostly hold up when employing the imputed datasets: Democracy thus seems to boost the share of income going to wages, even when addressing potential sample selection biases. However, many models including imputed data encounter problems either with the Ar- or Hansen tests, indicating these models may provide inconsistent results after all. This is exemplified by Models CXI and CXII on 1-year panels, and by Models CXIII and CXIV on 5-year panels.

In sum, the analysis does not provide unequivocal support for Rodrik's hypothesis that democracy increases wages. However, there is, at the very least, no evidence that democracy reduces WS. One could go further and note that the many different model specifications generally point in the same direction, and that an overweight of the evidence indicates that democracy does, indeed, increase wages. This positive estimate is reported in some models that account for sample-selection biases, the endogeneity of democracy, and country- and year-fixed effects. To the extent that WS is a good proxy, democracy seems to generate more egalitarian income distributions. There is, however, one additional concern that should be addressed, namely how choice of inequality measure affects estimates:

When running GMM models similar to above, but with the different Gini coefficients rather than WS as dependent variable, there is surprisingly little evidence of any inequality-reducing effect of democracy. Some System GMM models using the WDI Gini (Online Appendix Table A.33) or WIID-extracted disposable household Gini (Online Appendix Table A.35) even indicate that democracy increases inequality. Figure 2 illustrates the lack of correspondence between the WS and (for the sake of easing comparisons, reversed) WDI Gini measure for selected countries, and how this may influence inferences on democracy and inequality: Autocratic China has traditionally had relatively high Gini-scores and low WS-scores. China's Gini has, however, been declining over the sample period, whereas WS has not changed much. In contrast, the US' Gini-score has held relatively constant since 1960, whereas WS has decreased sharply. Poland and Malawi illustrate that also post-democratization changes in Gini and WS may go in different directions. Poland experienced reduction of its relatively high (reversed) Gini after democratization in the early 1990s, whereas WS increased throughout the decade. In contrast, Malawi's WS score was relatively unchanged after democratization, whereas its (reversed) Gini increased sharply.

Yet, there are, as discussed, problems with using the WDI and WIID data, particularly related to small sample sizes and potential for systematic selection biases. Hence, I tested GMM models using SWIID Gini data. WS measures share of gross income going to wages. It is therefore natural to robustness test the models above using the SWIID market income Gini. However, as Online Appendix Table A.31 indicates, such models fail to iden- 
Figure 2 - Democracy and inequality in China, Malawi, Poland, and The United States.

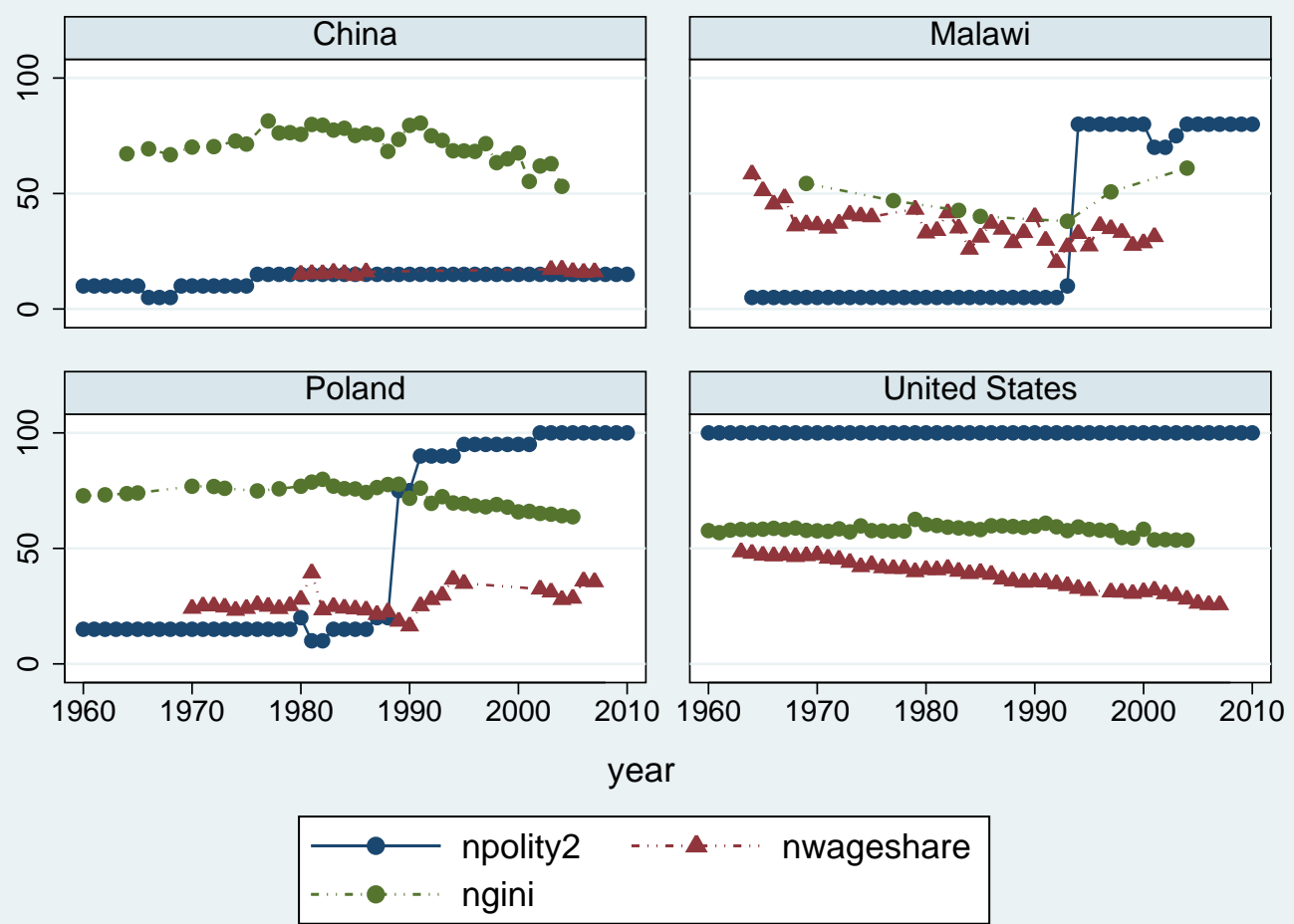

Notes: The figure shows normalized (0-100) annual PI, WS and (reversed) WDI Gini scores; high values indicate relatively democratic or egalitarian scores.

tify any inequality-reducing effect of democracy. When running these 12 models on the imputed datasets, two models find a significant inequalityreducing effect of democracy at 5 percent (Table A.41), but another specification actually shows a significant inequality-increasing effect of democracy. It could be that democracy reduces inequality in disposable income through promoting more progressive taxation systems and redistributive transfers. Yet, there is no clear evidence of this either. As Table A.31 and the selected Arellano-Bond model CX in Table 5 exemplifies, there is no evidence from the GMM models (as opposed to from the FE2SLS model CIII) of any effect of democracy on the disposable income Gini.

\subsubsection{Do various types of autocracies differ in inequality and redistribu- tion?}

The most obvious explanation for the divergent results on the inequalityreducing effect of democracy involves pointing to the poor quality of inequality data. If we treat all the measures discussed above as problematic proxies of (the same type of) income inequality concept, interpreting the mixed results boils down to acknowledging that there is a lack of robustness to the relationship. However, democracies may generally be good at increasing the wages of workers, whereas at least some types of autocracies 
pursue quite extensive redistributive strategies, for instance in the form of social welfare and educational policies (Haggard and Kaufman 2008; Knutsen and Rasmussen 2014), with important consequences (only) for disposable income inequality measures. ${ }^{17}$ In particular, several one-party dictatorships, both Communist and non-Communist, have relied on extensive redistribution to their relatively large winning coalitions. The Soviet Union (see Milanovic 1998) and Mexico under the PRI (see Magaloni 2006) are examples of party-based regimes combining extensive taxation or expropriation with subsequent redistribution to numerous relatively poor supporters. Such redistribution is captured by disposable income Gini coefficients, but not by WS (or market income SWIID Gini).

To investigate this further, I utilize data from Hadenius and Teorell (2007) and run models separating between monarchies, military regimes, one-party regimes, multi-party autocracies, other autocracies (including no-party regimes), and democracies. ${ }^{18}$ Appendix Table A.45 reports OLS PCSE models using WS, the two SWIID Ginis, and the redistribution measure from Solt (2009) based on differences between the two SWIID Ginis as dependent variables. No dictatorship type is associated with higher WS than democracies. Indeed, monarchies, military regimes and multiparty autocracies are all associated with a significantly (5 percent) lower WS. The monarchy coefficient indicates an 11.2 point drop in WS when going from a democracy to an autocratic monarchy.

Monarchies are also less egalitarian than democracies when using market income and disposable income Ginis as dependent variables. However, none of the other autocracy types are associated with significantly lower inequality than democracy on the Gini measures, and democracy does not outperform any autocratic regime type on progressive redistribution.

The most interesting result relates to the one-party dummy. Models using WS and the market income Gini do not find that one-party regimes have significantly different income inequalities from democracies. When applying the disposable income Gini, however, one-party regimes are seemingly associated with lower inequality. The weakly significant coefficient might be due to several one-party regimes - including a sizeable number of Communist regimes - pursuing extensive redistribution of income to their relatively poor winning coalitions through different programs (Haggard and Kauf-

\footnotetext{
${ }^{17}$ Interestingly, the democracy-inequality relationship may depend, more generally, on whether we measure inequality between groups (as WS; separating wage earners and capital owners) or individuals (as Gini coefficients). Huber et al. (2011) find that democracy reduces inequality between ethnic groups, but not within-group inequality or overall inequality. Hence, the notion that democracy mainly mitigates between-group inequalities - also when groups are not distinguished by ethnic characteristics - may constitute a viable explanation for the diverging results above.

${ }^{18}$ Hadenius and Teorell (2007) separate democracies and dictatorships by taking the average of normalized (0-10) scores on the PI and FHI, and set a threshold of 7.5 for being coded as democratic on this index.
} 
man 2008; Knutsen and Rasmussen 2014). This notion is further supported when employing the redistribution measure from Solt (2009); the one-party dummy remains significant, albeit only at 10 percent. Yet, these results are from robust, and it is thus premature to draw any clear conclusions on relationships between different types of autocracies, income inequality and redistribution $\sqrt{19}$ Still, the fact that there is no evidence, whatsoever, for any positive relationship between democracy and redistribution is noteworthy.

\section{Conclusion}

Fascinating theoretical work has been produced on the interrelationship between income inequality and democracy. Several empirical studies have also been conducted on whether and how income inequality affects democracy, and on whether and how democracy affects inequality. However, these studies have failed to fully account for different, potentially important, biases. When applying models that simultaneously adjust for country- and year-fixed effects as well as endogeneity bias, the analysis above suggests that there is no effect of income inequality on level of democracy. The nonresults could, in principle, be due to income inequality having quite different effects on the probabilities of democratization and democratic survival. High inequality might, for instance, increase democratization prospects through inducing grievances among the poor and reducing the credibility of elite commitments to redistribute (Acemoglu and Robinson 2000) - but impede democratic stability (Houle 2009). Nevertheless, the result that low inequality stabilizes existing democracies is very sensitive, and so is the relationship between inequality and democratization. In sum, there is little evidence that income inequality causally affects democracy in any simple and systematic manner.

In contrast, democracy seems to increase the share of income going to wages (see also Rodrik 1999), even when accounting for endogeneity and country- and year-fixed effects. Since wage earners are generally poorer than capital owners, this result also indicates that democracy reduces income inequality. However, there is no evidence of democracy reducing inequality - neither in gross nor in disposable income - when applying Gini-coefficient data from, for instance, the WIID or SWIID. Furthermore, some results indicated that one-party dictatorships may be associated with more redistribution and more egalitarian disposable income distributions than their democratic counterparts. Despite also these results lacking in robustness, they point to the potential importance of nuancing the regime

\footnotetext{
${ }^{19}$ When running GMM models accounting for the endogeneity of regime type, the oneparty coefficient often changes sign (see Table A.46). The other results are also quite sensitive. As indicated by the changes from Table A.45 to A.46, monarchies, for instance, may not increase inequality after all; it may rather be that monarchies form and survive in already inegalitarian contexts.
} 
variable in future research.

The clearest conclusion, however, is that choices of measures matter. Most notably, the inequality-reducing impact of democracy only holds when using WS. It is tempting to pursue substantial conclusions based on the diverging findings: Democracy reduces the inter-group inequality between wage earners and capital owners - possibly because democracies allow for freedom of association, including the freedom to form independent unions, thereby strengthening labor's bargaining power. Yet, democracy does not reduce broader societal inequalities, neither in terms of gross nor disposable incomes. While tempting, I would caution against prematurely drawing these conclusions. To the extent that all democracy and inequality measures tap common conceptual cores - and are associated with different reliability and validity issues - it may be safer, at this point, to conclude that there is no robust support for any causal effect (in either direction). With the data at hand, we simply do not have strongly founded knowledge of any aggregate effect of democracy on inequality, or of inequality on democracy. 


\section{References}

Acemoglu, D., Robinson, J.A., 2000. Why did the West extend the franchise? Democracy, inequality, and growth in historical perspective. Quarterly Journal of Economics 115, 1167-1199. doi: 10.1162/003355300555042

Acemoglu, D., Robinson, J.A., 2006. Economic origins of dictatorship and democracy. New York: Cambridge University Press. doi: $10.1017 /$ cbo9780511510809

Acemoglu, D., Robinson, J.A., Yared., P. 2008. Income and Democracy. American Economic Review 98, 808-842.

Acemoglu, D., Naidu, S., Restrepo, P., Robinson, J.A. 2013. Democracy, redistribution and inequality. Cambridge, MA.: NBER Working Paper No. 19746. doi: $10.3386 / w 19746$

Aidt, T.S., Jensen, P.S. 2013. Democratization and the size of government: Evidence from the long 19th century. Public Choice 157, 511-542. doi: $10.1007 / \mathrm{s} 11127-013-0073-y$

Albertus, M., Menaldo, V. 2014. Gaming democracy: Elite dominance during transition and the prospects for redistribution. British Journal of Political Science, Forthcoming. doi: 10.1017/s0007123413000124

Alesina, A., Devleeschauwer, A., Easterly, W., Kurlat, S., Wacziarg, R. 2003. Fractionalization. Journal of Economic Growth 8, 155-194.

Alesina, A., Perotti, R. 1996. Income distribution, political instability and investment. European Economic Review 40, 1203-1228. doi: 10.1016/00142921(95)00030-5

Ansell, B. , Samuels, D. 2010. Inequality and democratization: A contractarian approach. Comparative Political Studies 43, 1543-1574. doi: 10.1016/0014-2921(95)00030-5

Arellano, M., Bond, S. 1991. Some tests of specification for panel data: Monte Carlo evidence and an application to employment equations. Review of Economic Studies 58, 277-297. doi: 10.2307/2297968

Barro, R.J., Lee, J-W. 1993. International comparisons of educational attainment. Journal of Monetary Economics 32, 363-394. doi: 10.1016/03043932(93)90023-9

Beck, N., Katz, J.N. 1995. What to do (and not to do) with time-series cross-section data. American Political Science Review 89, 634-647. doi: $10.2307 / 2082979$ 
Blundell, R., Bond, S.R. 1998. Initial conditions and moment restrictions in dynamic panel data models. Journal of Econometrics 87, 115-143. doi: 10.1016/s0304-4076(98)00009-8

Boix, C.. 2003. Democracy and Redistribution. Cambridge: Cambridge University Press. doi: 10.1017/cbo9780511804960

Boix, C., Stokes, S.C. 2003. Endogenous democratization. World Politics 55, 517-549. doi: 10.1353/wp.2003.0019

Bollen, K.A., Jackman, R.W. 1985. Political democracy and the size distribution of income. American Sociological Review, 438-457. doi: $10.2307 / 2095432$

Bollen, K.A., Jackman, R.W. 1995. Income inequality and democratization revisited: Comment on Muller. American Sociological Review 60, 983-989. doi: $10.2307 / 2096436$

Bräutigam, D. 1997. Institutions, economic reform and democratic consolidation in Mauritius. Comparative Politics 30, 45-62. doi: 10.2307/422192

Bueno de Mesquita, B., Smith, A., Siverson, R.M., Morrow, J.D. 2003. The logic of political survival. Cambridge, Ma.: MIT Press.

Burkhart, Ross E. 1997. Comparative democracy and income distribution: Shape and direction of the causal Arrow. Journal of Politics 59, 148-164. doi: $10.2307 / 2998219$

Burkhart, R.E. 2007. Democracy, capitalism, and income inequality: seeking causal directions. Comparative Sociology 6, 481-507. doi: $10.1163 / 156913307 \times 233683$

Casper, G., Tufis, C. 2003. Correlation versus interchangeability: The limited robustness of empirical findings on democracy using highly correlated data sets. Political Analysis 11, 196-203. doi: 10.1093/pan/mpg009

Chabal, P., Daloz, J-P. 1999. Africa works: Disorder as political instrument. Oxford: James Currey. doi: 10.2307/20049597

Cheibub, J.A. 1998. Political regimes and the extractive capacity of governments: Taxation in democracies and dictatorships. World Politics 50, 349376. doi: $10.1017 / \mathrm{s} 0043887100012843$

Cheibub, J.A, Gandhi, J., Vreeland, J. 2010. Democracy and dictatorship revisited. Public Choice 143, 67-101.

Chong, A. 2004. Inequality, democracy, and persistence: Is there a political Kuznets curve? Economics \& Politics 16, 189-212. doi: 10.1111/j.14680343.2004.00137.x 
Dahl, R.A. 1989. Democracy and its critics. New Haven: Yale University Press.

Deyo, F.C. 1998. Industrial flexibility, economic restructuring and East Asian labor. In the four Asian tigers: Economic development and the global political economy, Ed. Kim, E.-M. Academic Press, 184-207. doi: 10.1016/b978012407440-8/50019-4

Diamond, L., Morlino. L. 2005. Introduction. In assessing the quality of democracy, Ed. Diamond, L., Morlino, L. Baltimore: Johns Hopkins University Press, ix-xliii.

Drèze, J., Amartya, S. 2002. Democratic practice and social inequality in India. Journal of African and Asian Studies 37, 6-37. doi: $10.1177 / 002190960203700202$

Engerman, S.L., Sokoloff, K.L 1997. Factor endowments, institutions, and differential paths of growth among new world economies: A view from economic historians of the United States. In How Latin America Fell Behind, Ed. Haber, S. Stanford: Stanford University Press, 260-304.

Freeman, J.R., Quinn, D.P. 2012. The economic origins of democracy reconsidered. American Political Science Review 106, 58-80. doi: $10.1017 / \mathrm{s} 0003055411000505$

Galbraith, J.K., Kum, H. 2005. Estimating the inequality of household incomes: Toward a dense and consistent global data set. Review of Income and Wealth 51, 115-143. doi: 10.1111/j.1475-4991.2005.00147.x

Gandhi, J. 2008. Dictatorial institutions and their impact on economic growth. European Journal of Sociology 49, 3-30. doi: $10.1017 / \mathrm{s} 0003975608000015$

Gates, S., Hegre, H., Jones, M.P., Strand, H. 2006. Institutional inconsistency and political instability: Polity duration, 1800-2000. American Journal of Political Science 50, 893-908. doi: 10.1111/j.1540-5907.2006.00222.x

Gerry, C.J., Mickiewicz, T.M. 2008. Inequality, democracy and taxation: Lessons from the post-communist transition. Europe-Asia Studies 60, 89111. doi: $10.1080 / 09668130701760356$

Gradstein, M., Milanovic, B. 2004. Does liberté = egalité? A survey of the empirical links between democracy and inequality with some evidence on the transition economies. Journal of Economic Surveys 18, 515-537. doi: 10.1111/j.0950-0804.2004.00229.x

Greene, W.H. 2003. Econometric analysis. 5th Edition. Upper Saddle River: Prentice-Hall. 
Grossman, G.M., Helpman, E. 2001. Special interest politics. Cambridge, Ma.: The MIT Press.

Hadenius, A., Teorell, J. 2007. Pathways from authoritarianism. Journal of Democracy 18, 143-156. doi: 10.1353/jod.2007.0009

Haggard, S., Kaufman, R.R. 2008. Development, democracy, and welfare states: Latin America, East Asia, and Eastern Europe. Princeton: Princeton University Press.

Haggard, S., Kaufman., R.R. 2012. Inequality and regime change: Democratic transitions and the stability of democratic rule. American Political Science Review 106, 495-516. doi: 10.1017/s0003055412000287

Honaker, J., King, G. 2010. What to do about missing values in time-series cross-section data. American Journal of Political Science 54, 561-581. doi: 10.1111/j.1540-5907.2010.00447.x

Houle, C. 2009. Inequality and democracy: Why inequality harms consolidation but does not affect democratization. World Politics 61, 589-622. doi: $10.1017 / \mathrm{s} 0043887109990074$

Huber, J.D., Ogorzalek, T.K, Gore, R. 2011. Democracy, targeted redistribution and ethnic inequality. New York: Columbia University. Working Paper.

Huntington, S.P. 1991. The third wave: Democratization in the late Twentieth century. Norman: University of Oklahoma Press.

Knutsen, C.H. 2011a. Democracy, dictatorship and protection of property rights. Journal of Development Studies 47, 164-182. doi: $10.1080 / 00220388.2010 .506919$

Knutsen, C.H. 2011b. The economic effects of democracy and dictatorship. PhD thesis. University of Oslo, Department of Political Science.

Knutsen, C.H., Rasmussen, M. 2014. The autocratic welfare state: Resource distribution, credible commitments and regime survival. University of Oslo and Aarhus University: Working paper. doi: 10.2139/ssrn.2482593

Kuran, T.. 1989. Sparks and prairie fires: A theory of unanticipated political revolution. Public Choice 61, 41-74. doi: 10.1007/bf00116762

Kuznets, S. 1955. Economic growth and income inequality. American Economic Review 45, 1-28.

Lake, D.A., Baum, M.A. 2001. The invisible hand of democracy: Political control and the provision of public services. Comparative Political Studies 34, 587-621. doi: 10.1177/0010414001034006001 
Lambert, P.J. 2001. The distribution and redistribution of Income. New York: Palgrave.

Leamer, E.E., Maul, H., Rodriguez, S., Schott, P.K., 1999. Does natural resource abundance increase Latin American income inequality? Journal of Development Economics 59, 3-42. doi: 10.1016/s0304-3878(99)00004-8

Li, Hongyi, L.S., Zou, H-F. 1998. Explaining international and intertemporal variations in income inequality. Economic Journal 108, 26-43. doi: $10.1111 / 1468-0297.00271$

Lindert, P.H. 2005. Growing public: Social spending and economic growth since the Eighteenth century. Volume 1. Cambridge: Cambridge University Press.

Lipset, S.M. 1959. Some social requisites of democracy: Economic development and political legitimacy. American Political Science Review 53, 69105. doi: $10.2307 / 1951731$

Maddison, A. 2007. Contours of the world economy, 1-2030 AD. Oxford: Oxford University Press.

Magaloni, B. 2006. Voting for autocracy: Hegemonic party survival and its demise in Mexico. New York: Cambridge University Press.

Marshall, M.G., Jaggers, K. 2002. Polity IV project - Dataset users' manual. College Park: Program Center for International Development and Conflict Management, University of Maryland. Manual.

Meltzer, A., Scott, R. 1981. A rational theory of the size of government. Journal of Political Economy 89, 914-927. doi: 10.1086/261013

Milanovic, B. 1998. Income, inequality, and poverty during the transition from planned to market economy. Washington D.C.: The World Bank.

Miller, M.K. 2014. Democratic pieces: Autocratic elections and democratic development since 1815. British Journal of Political Science, Forthcoming. doi: $10.1017 / \mathrm{s} 0007123413000446$

M , J., Skaaning, S-E. 2013. Autocracies, democracies, and the violation of civil liberties. Democratization 20, 82-106. doi: $10.1080 / 13510347.2013 .738863$

Muller, E.N. 1988. Democracy, economic development, and income inequality. American Sociological Review 53, 50-68. doi: 10.2307/2095732

Muller, E.N. 1995. Economic determinants of democracy. American Sociological Review 60, 966-982. 
Mulligan, C.B., Sala-i Martin, X., Gill, R. 2004. Do democracies have different public policies than non-democracies? Journal of Economic Perspectives 18, 51-74. doi: 10.1257/089533004773563430

Munck, G.L., Verkuilen, J. 2002. Conceptualizing and measuring democracy: Evaluating alternative indices. Comparative Political Studies 35, 5-34. doi: $10.1177 / 0010414002035001001$

Pemstein, D., Meserve, S., Melton, J. 2010. Democratic compromise: A Latent variable analysis of ten measures of regime type. Political Analysis 21, 1-24. doi: $10.1093 / \mathrm{pan} / \mathrm{mpq020}$

Piketty, T. 2014. Capital in the Twenty-First century. Cambridge, Ma.: The Belknapp Press of Harvard University Press.

Przeworski, A. 2010. Democracy and the limits of self-government. Cambridge: Cambridge University Press.

LPrzeworski, A., Alvarez, M.E., Cheibub, J.A., Limongi, F. 2000. Democracy and development. Political institutions and well-being in the world, 19501990. Cambridge: Cambridge University Press.

Rodrik, D. 1999. Democracies pay higher wages. The Quarterly Journal of Economics 114, 707-738. doi: 10.1162/003355399556115

Rogowski, R.L. 2009. What changes inequality, and what does inequality change? Paper presented at the 50th Annual ISA Conference in New York.

Roodman, D. 2009a. How to do xtabond2: An introduction to difference and system GMM in Stata. Stata Journal 9, 86-136.

Roodman, D. 2009b. A note on the theme of too many instruments. Oxford Bulletin of Economics and Statistics 71, 135-158. doi: 10.1111/j.14680084.2008.00542.x

Ross, M. 2001. Does oil hinder democracy? World Politics 53, 325-361. doi: 10.1353/wp.2001.0011

Ross, M.L. 2011. Replication data for: Oil and gas production and value, 1932-2009, Version 4. Data set.

Rubinson, R., Quinlan, R., 1977. Democracy and social inequality: A reanalysis. American Sociological Review 42, 611-623. doi: 10.2307/2094559

Saint-Paul, G., Verdier, T. 1993. Education, democracy and growth. Journal of Development Economics 42, 399-407. doi: 10.1016/0304-3878(93)90027-k

Sirowy, L., Inkeles, A. 1990. The effects of democracy on economic growth and inequality: A review. Studies in Comparative International Development 25, 126-156. doi: $10.1007 /$ bf02716908 
Solt, F. 2009. Standardizing the world income inequality database. Social Science Quarterly 90, 231-242. doi: 10.1111/j.1540-6237.2009.00614.x

Solt, Frederick. 2014. The standardized world income inequality database. University of Iowa: Working Paper.

Stasavage, D. 2005. Democracy and educational spending in Africa. American Journal of Political Science 49, 343-358.

Teorell, J. 2010. Determinants of democratization: Explaining regime change in the world, 1972-2006. Cambridge: Cambridge University Press.

Timmons, J.F. 2010. Does democracy reduce economic inequality? British Journal of Political Science 40, 741-757. doi: 10.1017/s0007123410000165

UNIDO. 2011. INDSTAT2 2011 ISIC Rev. 3. Data set.

UNU-WIDER. 2008. World income inequality database, Version 2.0c. Data set.

Vanhanen, T.. 1997. Prospects of democracy: A study of 172 countries. London: Routledge.

Ziblatt, D. 2008. Does landholding inequality block democratization? A test of the bread and democracy thesis and the case of Prussia. World Politics 60, 610-641. doi: 10.1353/wp.0.0021 